\title{
Effect of Alcohol on Serum Folate Level
}

\author{
EdWARd R. EichNeR and Robert S. HILLMan \\ From the Department of Medicine, Division of Hematology, University of \\ Washington School of Medicine, Seattle, Washington 98105, and the \\ Department of Medicine, Louisiana State University School of Medicine, \\ Shreveport, Louisiana 71130
}

\begin{abstract}
A в S T RAC T Alcohol was given orally and intravenously to normal and chronic alcoholic volunteers to study its effect on folate metabolism. Oral alcohol, given to nine subjects on a low folate diet, caused a greater fall in serum Lactobacillus casei folate levels than that seen in eight subjects on a low folate diet alone. This alcohol-induced fall in serum folate level occurred largely during the 1st day of the protocol. Although brief infusions of intravenous ethanol had no effect on serum folate level, a $13 \mathrm{~h}$ infusion caused a striking fall in serum folate level between the 8th and 10th $\mathrm{h}$. When ethanol was stopped, the serum folate level returned rapidly to normal. Two chronic alcoholic subjects with different basal levels of serum folate were studied for several weeks on a low folate diet plus alcohol. The serum folate level fell promptly in each subject, rose when alcohol was temporarily stopped, and fell when alcohol was resumed. Folate-deficient megaloblastic anemia developed in $3 \mathrm{wk}$ in the subject with initially marginal serum folate levels, but failed to develop in almost 7 wk in the subject with normal folate stores, as reflected by initially high serum folate levels. Thus, the alcoholinduced fall in serum folate level was apparently not a result of depletion of folate stores. In vitro experiments ruled out an assay artifact as an explanation for the alcohol-induced fall in serum $L$. casei folate level. It seems likely that alcohol interferes with the delivery of $n-5$ methyltetrahydrofolic acid from storage areas.
\end{abstract}

\section{INTRODUCTION}

Alcohol has been incriminated in the development of diverse hematologic abnormalities (1-4), the prevalence of which appears to vary considerably with the socioeconomic class, dietary and drinking patterns, and general health of the alcoholic population studied (5). Malnourished chronic alcoholics admitted to general care

Received for publication 10 August 1972 and in revised form 17 November 1972. hospitals show the most striking prevalence of megaloblastic hematopoiesis and ring sideroblastic marrow abnormality $(1,6,7)$. Alcohol seems to accelerate the induction of megaloblastic anemia in subjects on a low folate diet (8). Moreover, alcohol can prevent or abort the hematologic response to folic acid in subjects with folate-deficient anemia (9). Thus, alcohol seems to have a specific detrimental effect on folate metabolism.

The present study focuses on early changes in folate metabolism upon administration of alcohol to both normal and alcoholic subjects. It is shown that the ingestion of alcohol leads to a dramatic fall in the serum Lactobacillus casei folate level. Although the exact mechanism causing this decrease in serum folate is yet unknown, the work presented here argues against a simple explanation such as assay artifact and implicates a possible inhibition of delivery of $n$-5-methyltetrahydrofolic acid, the major folate metabolite in fasting serum, from storage sites.

\section{METHODS}

All volunteer subjects were studied in the Clinical Research Center of Harborview Medical Center, Seattle, Wash., under the guidelines of the Helsinki Declaration for human research. Before the study began, each individual underwent complete medical evaluation including determination of erythrocyte indices, leukocyte count and differential, platelet count, reticulocyte count, vitamin B-12 level, and liver function tests. A bone marrow aspiration was performed and serum folate levels were measured twice daily (7 a.m. [fasting] and 7 p.m.) while the subjects were maintained on a diet containing $150-250 \mu \mathrm{g} /$ day of folate as measured by $L$. casei assay without chick pancreas incubation (10). Subsequently, these measurements were repeated at varying intervals according to the individual study protocol. Liver function tests and electrolytes were monitored at least weekly in all prolonged studies. Average daily phlebotomy was limited to less than $20 \mathrm{ml}$ whole blood.

Initially, 17 subjects were studied for periods of 1-2 wk while on a folate-deficient diet either with or without alcohol. None of these subjects had received folic acid supplements during the previous control period on the normal folate diet. When maintained on the low folate diet (containing less than $5 \mu \mathrm{g} /$ day folate without chick pancreas 
conjugase and approximately $15-25 \mu \mathrm{g} /$ day folate with conjugase incubation), all subjects received supplements of potassium chloride, multivitamins (without folic acid), thiamine hydrochloride, and ferrous gluconate $(600 \mathrm{mg}$ three times a day). Those subjects who were also placed on oral alcohol ingested 1 ounce of 95\% pharmaceutical grade ethanol every $2 \mathrm{~h}$ while awake for a daily intake equivalent to 1 pint of commercial whiskey. This amount of alcohol did not interfere with the subjects' daily functions and no alcohol withdrawal symptoms were seen in any subject.

Precautions were taken to make caloric and folate intake comparable in the two groups during the test regimens. The subjects not receiving alcohol were encouraged to eat hard candy and drink 7-Up (both free of folate by assay) in amounts calculated to equal the caloric content of the alcohol. Most of the subjects on alcohol ate all or almost all of the low folate diet each day, with coaxing as needed by the dietary personnel. Though some subjects lost weight, in no case was the degree of weight loss greater in a subject on alcohol than in a subject on the low folate diet alone. Other protocol studies were as follows.

(a) Four subjects on the low folate diet had serum folate and blood ethanol levels repeated at 4-h intervals during and after a $20-30 \mathrm{~h}$ period of alcohol ingestion.

(b) Two subjects were maintained on the low folate diet with intermittent alcohol ingestion for $6 \frac{1}{2}$ and 7 wk respectively. Both subjects ate all of the low folate diet each day, and neither subject lost any weight during the study. One subject was placed on the normal diet without alcohol for
8 days and then switched to the low folate diet with alcohol. After 1 wk, alcohol was discontinued for 7 days while the low folate diet was continued. Alcohol was then reinstituted and maintained until megaloblastic erythropoiesis appeared. Finally, normal erythropoiesis was restored by resuming the normal folate diet and stopping alcohol. The other subject was placed on a normal folate diet for 11 days with 5 $\mathrm{mg}$ of folic acid orally twice a day for the first 5 of these 11 days. The low folate diet with alcohol was begun on day 12. After 1 wk, the alcohol was discontinued for 7 days while the low folate diet was continued. Alcohol was then reinstituted for $4 \mathrm{wk}$. During these studies of the longterm effect of alcohol, repeated measurements of erythrocyte indices, reticulocyte counts, and serum folate levels were made. Bone marrow aspirations and plasma iron turnovers were done every 7-10 days.

(c) Five fasting subjects (including three physicians) received infusions of a $10 \%$ solution of absolute ethanol in $5 \%$ dextrose and water. Four of these subjects received $50 \mathrm{ml}$ ethanol intravenously ( $500 \mathrm{ml}$ of the above solution) in 24, 28, 40, and $44 \mathrm{~min}$, respectively. Blood alcohol levels and serum and urine $L$. case $i$ folate levels were monitored before, during, and for $4 \mathrm{~h}$ after the infusion. One subject received a $13 \mathrm{~h}$ ethanol infusion, during which $40 \mathrm{ml}$ of ethanol as a $10 \%$ solution was given in the first $45 \mathrm{~min}$, followed by a steady infusion of $2 \mathrm{ml} / \mathrm{min}$ for the next $12 \mathrm{th}$. In this study, serum folate levels were measured every $2 \mathrm{~h}$ and urine was collected in 4-h samples for $L$. casei assay.

TABLE I

Effect of Low Folate Diet and Alcohol on Serum Folate Levels

\begin{tabular}{|c|c|c|c|c|c|c|c|c|c|c|c|}
\hline \multirow[b]{2}{*}{ Subject } & \multicolumn{3}{|c|}{ Basal folate levels } & \multicolumn{5}{|c|}{$\begin{array}{c}\text { Daily folate levels for first } 6 \text { days } \\
\text { on low folate diet }\end{array}$} & & \multicolumn{2}{|c|}{$\begin{array}{c}\text { Fall in folate from } \\
\text { the middle of the } \\
\text { basal range }\end{array}$} \\
\hline & Range & (No. of days) & Day 0 & 1 & 2 & 3 & 4 & 6 & & Day 1 & Day 6 \\
\hline & $n g / m l^{*}$ & & $n g / m l$ & $n g / m l$ & $n g / m l$ & $n g / m l$ & $n g / m l$ & $n g / m l$ & & $\%$ & $\%$ \\
\hline 1 & $16.0-20.0$ & (4) & 17.5 & 16.0 & 15.6 & 18.0 & 13.2 & 12.4 & & 11 & 31 \\
\hline 2 & $12.8-14.0$ & (5) & 13.0 & 11.8 & 14.0 & 12.0 & 11.2 & 10.5 & & 12 & 22 \\
\hline 3 & $13.2-15.0$ & (5) & 13.6 & 10.6 & 9.5 & 9.4 & 8.2 & 7.6 & & 25 & 46 \\
\hline 4 & $9.0-13.0$ & (7) & 11.5 & 11.8 & 11.0 & 8.0 & - & 8.4 & & 0 & 24 \\
\hline 5 & $7.5-10.0$ & (6) & 8.2 & 8.0 & 7.8 & - & - & 7.0 & & 9 & 20 \\
\hline 6 & $5.6-6.5$ & (5) & 6.2 & 6.4 & - & 6.5 & - & 5.0 & & 0 & 17 \\
\hline 7 & $4.0-6.8$ & (10) & 6.8 & 6.8 & 5.0 & - & - & 3.8 & & 0 & 30 \\
\hline \multirow[t]{2}{*}{8} & $3.6-5.7$ & $(5)$ & 4.2 & 4.0 & 3.4 & 3.4 & - & 2.5 & & 14 & $\underline{46}$ \\
\hline & & & & & & & & & Mean & 9 & 30 \\
\hline 1 & $33.0-40.0$ & (5) & 34.0 & 9.4 & 3.6 & - & - & - & & 74 & $90 \ddagger$ \\
\hline 2 & $22.0-35.0$ & (5) & 27.4 & - & 12.5 & 9.0 & 6.0 & 6.8 & & - & 76 \\
\hline 3 & $12.4-15.0$ & (4) & 13.1 & 9.6 & 6.0 & 6.4 & 6.0 & 6.2 & & 30 & 55 \\
\hline 4 & $7.5-13.0$ & (7) & 10.8 & 6.5 & 4.4 & 4.1 & 3.6 & 3.7 & & 37 & 64 \\
\hline 5 & $7.0-12.0$ & (7) & 10.5 & 5.4 & 3.9 & 6.2 & 5.4 & 4.1 & & 43 & 57 \\
\hline 6 & $6.0-7.5$ & (7) & 7.0 & 3.8 & 4.0 & 3.8 & 3.1 & 2.4 & & 44 & 64 \\
\hline 7 & $5.0-7.0$ & (7) & 6.3 & 1.3 & 2.2 & 1.9 & 2.4 & 2.6 & & 78 & 57 \\
\hline 8 & $4.6-7.0$ & (6) & 6.8 & 3.1 & 2.6 & 2.4 & 2.4 & 2.0 & & 47 & 66 \\
\hline \multirow[t]{2}{*}{9} & $3.6-6.5$ & (4) & 5.7 & 2.5 & 1.6 & 1.6 & 2.0 & - & & 51 & $60 \ddagger$ \\
\hline & & & & & & & & & Mean & 51 & 65 \\
\hline
\end{tabular}

* Each value represents the mean of a 7 a.m. (fasting) and 7 p.m. sample.

$\ddagger$ Calculated from value on day nearest day 6 . 

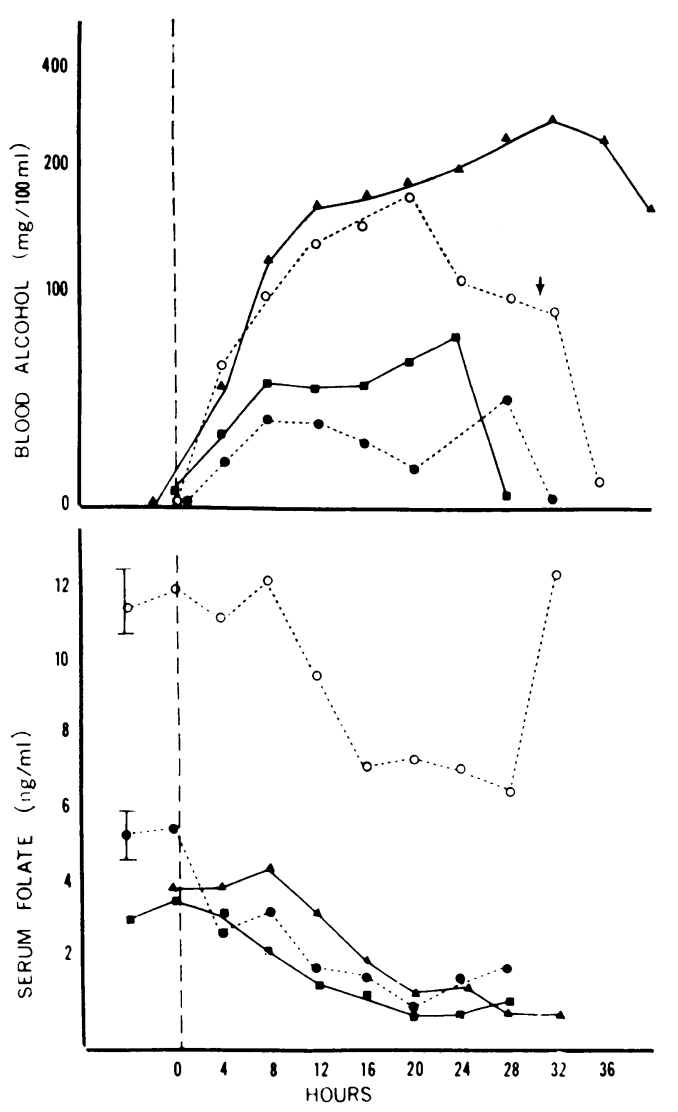

FIgure 1 Serial blood alcohol and serum $L$. casei folate levels in four subjects on the low folate diet who drank 1 ounce of $95 \%$ ethanol every $2 \mathrm{~h}$ for $20-30 \mathrm{~h}$. All subjects had a rapid decline in serum folate levels.

All serum folate levels were assayed by the aseptic $L$. casei method of Herbert (11). L. casei assays on urine were done on samples from 4-h collections which were kept frozen in $1 \%$ ascorbate for no more than 1 wk. Plasma iron turnovers were done by the method of Bothwell and Finch (12). Bone marrow morphology was characterized on cover slip smears of aspirated particles stained with Wright's stain. Iron stores and sideroblasts were characterized on particle smears stained with prussian blue. Blood ethanol determinations were done by the alcohol dehydrogenase method (13).

\section{RESULTS}

Serum folate levels were measured twice daily in 17 subjects during a control (basal) period on a normal folate diet, and after initiating either the low folate diet alone (eight subjects), or the low folate diet plus alcohol (nine subjects, Table I). These two groups were comparable in that there was no significant difference between the mean basal serum folate levels (10.2 and 13.6 $\mathrm{ng} / \mathrm{ml}$, respectively; $t=0.789, P>0.20)$. In each subject, the range of basal folate values during the 4-10 days of the control diet was reasonably narrow, and seemed to constitute a plateau. However, since there was some variation in serum folate levels from day to day during the basal periods, the percentage fall in serum folate level during the test regimens was calculated from the middle of the basal range rather than from the last folate value of the basal period.

The group on the low folate diet alone had a mean fall in serum folate level of $9 \%$ on the 1st day of that diet, and by day 6 the mean decrease was 30\%. In contrast, the group on the low folate diet plus alcohol had a mean fall in serum folate level of $51 \%$ on the 1 st day and by day 6 the mean decrease was $65 \%$. The group receiving alcohol thus had a significantly greater fall in serum folate level (on day $1, t=6.15, P<0.001$; on day 6 , $t=9.15, P<0.001)$. However, there was no significant difference between the two groups in the decrease in serum folate level from day 1 to day 6 . Thus, the significant alcohol-induced fall in serum folate level seemed to occur during the 1st day on alcohol (Table I).

To further investigate the precise timing of this alcohol-induced fall in serum folate level, blood alcohol and serum folate levels were measured at 4-h intervals in four subjects during and after a $20-30 \mathrm{~h}$ period of alcohol ingestion (Fig. 1). Unfortunately, because of apparent variations in absorption and metabolism of the alcohol, peak blood alcohol levels varied from 35 to $275 \mathrm{mg} / 100$ $\mathrm{ml}$. Still, a rapid reduction in serum folate level was seen in all subjects. Three subjects (solid markers) had a greater than $50 \%$ reduction in serum folate level to below $2 \mathrm{ng} / \mathrm{ml}$ by the $20 \mathrm{th} \mathrm{h}$. One subject (open circles) showed little change in serum folate level until after the 8 th $\mathrm{h}$ when the level began to fall rapidly. By the 16 th $\mathrm{h}$ the level was down to approximately $60 \%$ of the control value. The rapid rise in serum folate back to the control level between hours 28 and 32 in this subject was probably caused in part by an intravenous injection of $5 \mathrm{mg}$ of folic acid ${ }^{1}$ at the 30th $\mathrm{h}$ (arrow, Fig. 1), although with a half-life of approximately 15 min for intravenously injected folic acid $(14,15)$, the great majority of this folic acid would have been cleared from the plasma within $2 \mathrm{~h}$.

In an attempt to make the alcohol stimulus more uniform, four studies were carried out in fasting subjects, using a single bolus of intravenous ethanol sufficient to raise the blood alcohol to approximately $100 \mathrm{mg} / 100 \mathrm{ml}$ (actual values obtained ranged from 60 to $120 \mathrm{mg} / 100$ $\mathrm{ml})$. Blood alcohol and serum folate levels were then measured at 15-30-min intervals for the next $4 \mathrm{~h}$. During this time, there was no decrease in serum folate regardless of the initial level. Subsequently, a single longterm infusion study was performed using serial blood alcohol determinations to control the rate of infusion and

1 "Folvite," Lederle Labs. Division, American Cyanamid Co., Pearl River, N. Y 
maintain the blood alcohol level between 90 and $110 \mathrm{mg} /$ $100 \mathrm{ml}$ for $16 \mathrm{~h}$ (Fig. 2). Once again, little change from basal folate values of $14-18 \mathrm{ng} / \mathrm{ml}$ was noted until after the 8th $\mathrm{h}$, when the level fell rapidly to $6-8 \mathrm{ng} / \mathrm{ml}$. Serial urine collections failed to show any significant change in the excretion of $L$-casei-active folate throughout the study. When ethanol was stopped, the serum folate level rapidly returned toward normal.

The possibility that alcohol interferes with the $L$. casei assay of serum folate was strongly considered. The following experiments were performed to evaluate this theory.

Heating experiments. On the chance that alcohol or acetaldehyde was inhibiting bacterial growth, sera from subjects on the oral and intravenous alcohol protocols were heated to 37 and $50^{\circ} \mathrm{C}$ for up to $24 \mathrm{~h}$ to drive off volatile substances (Table II). Control sera ( $8-15 \mathrm{ng} /$ $\mathrm{ml}$ ) showed no drop in $L$. casei value until after $3 \mathrm{~h}$ at $50^{\circ} \mathrm{C}$ and $16-24 \mathrm{~h}$ at $37^{\circ} \mathrm{C}$. While measurable alcohol
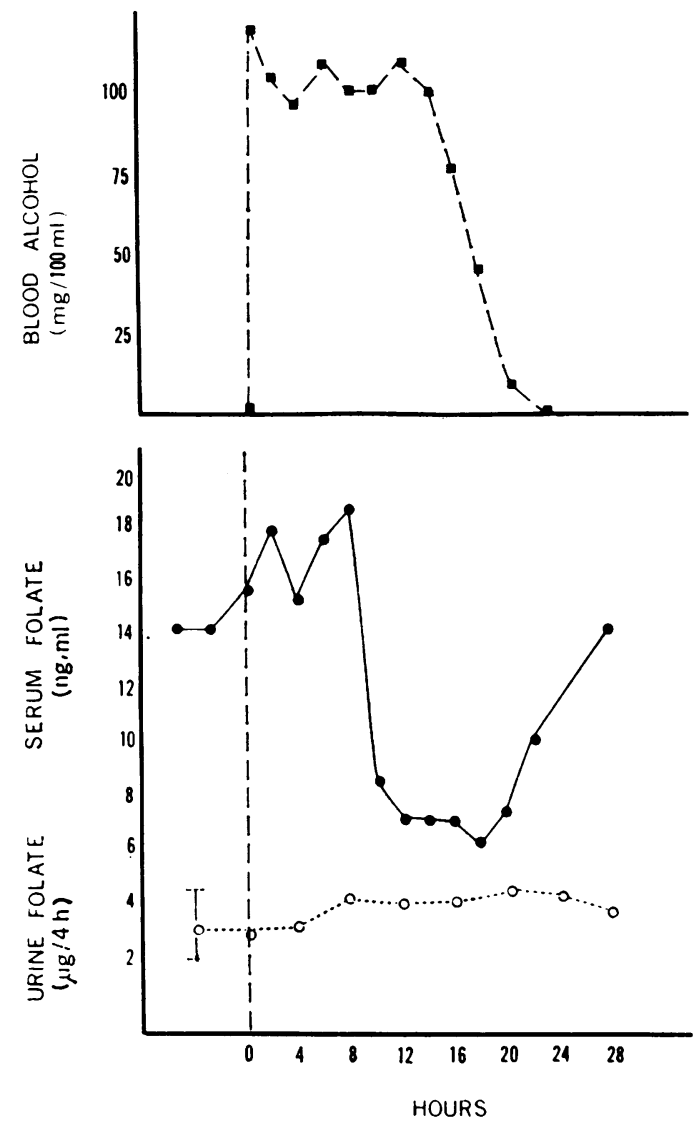

FIgURE 2 Serial blood alcohol, serum folate, and urinary folate levels in a subject who received a $13 \mathrm{~h}$ infusion of ethanol. A sharp decline in serum folate was noted between hours 8 and 10, followed by a prompt return to initial level when ethanol was stopped. There was no significant change in urinary folate excretion.
TABLE II

Effect of Heat on $L$. casei Folate Content of Sera Containing Alcohol

\begin{tabular}{ccccccc}
\hline \multicolumn{2}{c}{$50^{\circ} \mathrm{C}$ incubation } & & \multicolumn{4}{c}{$37^{\circ} \mathrm{C}$ incubation } \\
\cline { 1 - 5 } 0 time & $3 \mathrm{~h}$ & & 0 time & $6 \mathrm{~h}$ & $18 \mathrm{~h}$ & $24 \mathrm{~h}$ \\
\hline$n g / m l$ & $n g / m l$ & & $n g / m l$ & $n g / m l$ & $n g / m l$ & $n g / m l$ \\
1.3 & 1.0 & & 1.6 & 2.0 & 2.2 & 1.3 \\
2.4 & 1.4 & & 2.6 & 2.1 & 2.4 & 2.0 \\
2.1 & 2.6 & & 3.4 & 2.5 & 2.2 & 1.9 \\
1.2 & 1.0 & & 4.0 & 3.7 & 3.9 & 3.2 \\
1.3 & 1.0 & & 1.0 & 1.8 & 1.2 & 1.1 \\
1.4 & 1.0 & & 1.0 & 1.5 & 1.6 & 1.6 \\
3.3 & 1.9 & & & & \\
1.6 & 1.0 & & & & \\
\hline
\end{tabular}

content of the test sera fell to zero, no significant rise in folate levels was detected.

Recovery studies. Recovery studies were performed by addition of either folic acid or normal serum (containing mainly $n$-5-methyltetrahydrofolic acid) to control sera and to sera containing alcohol (Table III). Recovery uniformly approached or slightly exceeded $100 \%$, ruling out the presence of an excess of an $L$. casei inhibitor and also ruling out rapid destruction of added vitamin by alcohol.

Influence of alcohol and its major metabolites on the L. casei assay. The metabolism of alcohol produces trace levels of acetaldehyde in the blood (16) and also elevates

TABLE III

A. Recovery of Folic Acid Added to Sera Containing Alcohol

\begin{tabular}{cccccc}
\hline \multirow{2}{*}{$\begin{array}{c}\text { Original } \\
\text { folate } \\
\text { value }\end{array}$} & Alcohol & & \multicolumn{4}{c}{$\begin{array}{c}\text { Final folate value after addition of } \\
\text { folic acid as listed (ng/ml) }\end{array}$} \\
\cline { 2 - 6 } & content & +2 & +4 & +8 & +10 \\
\hline$n g / m l$ & $m g / 100 ~ m l$ & $n g / m l$ & $n g / m l$ & $n g / m l$ & $n g / m l$ \\
6.0 & 10 & 7.6 & 10.5 & 13.4 & 16.6 \\
4.5 & 80 & 6.4 & 10.0 & 13.0 & 19.0 \\
1.0 & 150 & 3.2 & 4.9 & - & 11.0 \\
\hline
\end{tabular}

B. Recovery of n-5-Methyltetrahydrofolic Acid Added to Sera Containing Alcohol

\begin{tabular}{ccccc}
\hline & \multicolumn{3}{c}{$\begin{array}{c}\text { Expected } \\
\text { value } \\
\text { after }\end{array}$} \\
$\begin{array}{c}\text { Original } \\
\text { folate } \\
\text { value }\end{array}$ & Alcohol & $\begin{array}{c}\text { Control } \\
\text { serum } \\
\text { content }\end{array}$ & $\begin{array}{c}50: 50 \\
\text { mix }\end{array}$ & $\begin{array}{c}\text { Observed } \\
\text { value }\end{array}$ \\
\hline$n g / m l$ & $m g / 100 m l$ & $n g / m l$ & $n g / m l$ & $n g / m l$ \\
8.6 & 10 & 18.6 & 13.6 & 13.0 \\
9.0 & 10 & 18.6 & 13.8 & 14.0 \\
2.3 & 156 & 18.6 & 10.5 & 11.5 \\
0.6 & 150 & 8.7 & 4.7 & 6.0 \\
\hline
\end{tabular}

Effect of Alcohol on Serum Folate Level 
TABLE IV

A. Effect of Ethanol, Lactate, and Uric Acid

Folate value* after incubation $\left(37^{\circ} \mathrm{C}\right)$

\begin{tabular}{|c|c|c|c|}
\hline \multirow[b]{2}{*}{ Original folate value* } & \multicolumn{3}{|c|}{ Folate value* after incubation $\left(37^{\circ} \mathrm{C}\right)$} \\
\hline & $1 \mathrm{~h}$ & $2 \mathrm{~h}$ & $16 \mathrm{~h}$ \\
\hline$n g / m l$ & $n g / m l$ & $n g / m l$ & $n g / m l$ \\
\hline 15.8 (control) & 15.0 & 18.0 & 17.5 \\
\hline 15.8 (test) & 16.4 & 19.3 & 17.9 \\
\hline \multicolumn{4}{|c|}{ B. Effect of Ethanol, Acetaldehyde, Lactate, and Acetate } \\
\hline & \multicolumn{3}{|c|}{ Folate value* after incubation $\left(37^{\circ} \mathrm{C}\right)$} \\
\hline Original folate value* & $1 \mathrm{~h}$ & $4 \mathrm{~h}$ & $24 \mathrm{~h}$ \\
\hline$n g / m l$ & $n g / m l$ & $n g / m l$ & $n g / m l$ \\
\hline \multicolumn{4}{|l|}{ Controls } \\
\hline 8.8 & 8.3 & 8.9 & 3.0 \\
\hline 8.4 & 8.2 & 9.0 & 3.0 \\
\hline \multicolumn{4}{|l|}{ Test Sera } \\
\hline 9.2 & 8.8 & 8.7 & 4.2 \\
\hline 9.7 & 8.0 & 8.4 & 3.9 \\
\hline 8.1 & 7.9 & 9.1 & 4.1 \\
\hline $8.4^{\prime}$ & 9.5 & 8.8 & 4.4 \\
\hline
\end{tabular}

* Each represents the mean of four determinations.

blood acetate (17). Hepatic pyruvate is converted to lactate, which can accumulate in the blood and cause hyperuricemia by inhibiting renal excretion of uric acid (18). Normal sera were incubated up to $24 \mathrm{~h}$ at $37^{\circ} \mathrm{C}$ with either ethanol, $450 \mathrm{mg} / 100 \mathrm{ml}$; sodium lactate, 70 $\mathrm{mg} / 100 \mathrm{ml}$; and uric acid, $20 \mathrm{mg} / 100 \mathrm{ml}$ (Table IV A); or ethanol, $150 \mathrm{mg} / 100 \mathrm{ml}$; acetaldehyde, $1 \mathrm{mg} / 100 \mathrm{ml}$; lactate, $10 \mathrm{mg} / 100 \mathrm{ml}$; and acetate, $20 \mathrm{mg} / 100 \mathrm{ml}$ ( Table IV B). In neither case was there any inhibition of $L$. case $i$ growth, and the serum folate levels were unchanged. Moreover, addition of acetaldehyde in unphysi-

TABLE V

Influence of Osmotic Effect of Alcohol on L. casei Assay

\begin{tabular}{cccccc}
\hline $\begin{array}{c}\text { Alcohol } \\
\text { content }\end{array}$ & $\begin{array}{c}\text { Serum } \\
\text { osmolality }\end{array}$ & \multicolumn{5}{c}{ Folate values* } \\
\hline$m g / 100 m l$ & $m o s m o l / k g$ & $n g / m l$ & $n g / m l$ & $n g / m l$ & $n g / m l$ \\
0 & 298 & 10.7 & 9.9 & 16.0 & 4.8 \\
79 & 320 & 9.9 & 12.2 & 18.0 & 4.2 \\
158 & 342 & 10.6 & 11.2 & - & - \\
237 & 363 & 10.0 & - & - & - \\
316 & 381 & - & 14.7 & 19.5 & - \\
395 & 402 & 9.9 & - & - & - \\
553 & 435 & - & 13.0 & 18.7 & - \\
790 & 495 & - & 14.0 & - & - \\
948 & 520 & - & 14.7 & 17.5 & 4.8 \\
\hline
\end{tabular}

* Four different sera were used; each value is the mean of six determinations. ologic concentrations up to $80 \mathrm{mg} / 100 \mathrm{ml}$ or lactic acid up to $1,200 \mathrm{mg} / 100 \mathrm{ml}$ failed to depress $L$. casei growth.

Potential depletion by alcohol of nonfolate substances required for $L$. casei growth. To exclude this possibility, folate-deficient serum from a subject who had been on a low folate diet without alcohol was combined with a serum from one of the intravenous alcohol tests. The dietdepleted, folate-deficient serum did not promote growth of $L$. case $i$ beyond that expected from its known folate content. Since circulating free fatty acids are sometimes decreased by short-term ethanol administration (19), oleic acid in concentrations up to $500 \mathrm{mg} / 100 \mathrm{ml}$ was added to test sera containing alcohol. There was no significant enhancement of $L$. casei growth.

Influence of osmotic effect of alcohol on $L$. casei assay. Ethanol has a marked osmotic effect (20). In the $L$. casei assay a standard inoculum of $0.1 \mathrm{ml}$ of serum from a subject with a high blood ethanol level might contain less plasma water and less folate than an identical inoculum from a normal control subject. To test this possibility, ethanol was added to normal serum to yield final concentrations ranging from 79 to $948 \mathrm{mg} / 100 \mathrm{ml}$. The measured serum osmolalities for these samples ranged from 320 to $520 \mathrm{mosmol} / \mathrm{kg}$ of water. The serum folate values of these samples were assayed without adjusting the serum inoculum for the presence of ethanol. There was no significant fall in the folate value of any of these samples when compared with the base-line control value (Table V).

The primary test of significance of the alcohol-induced fall in serum folate level is the speed of induction of tissue folate deficiency. To study this, two subjects were maintained on a low folate diet plus alcohol for several weeks (Fig. 3). One subject was transferred to the Clinical Research Center from the medical ward, where he had spent 10 days recuperating from a 1 wk alcoholic binge that had terminated 2 mo of sobriety. When he was admitted to the Clinical Research Center, his general health and liver function were normal. His serum folate level was borderline $(3.8-4.6 \mathrm{ng} / \mathrm{ml})$, but his hematocrit was $42 \%$ and his erythropoiesis was normoblastic by marrow morphology. During an 8 day control period, his serum folate level rose to $6.5 \mathrm{ng} / \mathrm{ml}$. The other subject was also a chronic alcoholic, but had been sober and eating well for several weeks before admission. When admitted, his general health and liver function were normal. His serum folate level was high-normal (11-14 $\mathrm{ng} / \mathrm{ml})$ and his hematologic status was normal. He was given supplemental folic acid for $\mathbf{5}$ days during the 11 day control period, raising his serum folate level to a peak of $42 \mathrm{ng} / \mathrm{ml}$. During the last 6 days of the control period, when he was not receiving supplemental folic acid, his serum folate level fell gradually to 30 $\mathrm{ng} / \mathrm{ml}$. With the start of the low folate diet and alcohol 
ingestion both subjects had a rapid fall in serum folate level to less than $50 \%$ of their starting values within 24-36 h (Fig. 3).

After $1 \mathrm{wk}$ on the alcohol, both subjects continued to have normoblastic erythropoiesis by marrow morphology and ferrokinetic studies, though the subject with the higher initial serum folate level showed a rise in serum iron level from 140 to $250 \mu \mathrm{g} / 100 \mathrm{ml}$. Alcohol was then stopped but the low folate diet was continued for the next 7 days. The serum folate level rose in both subjects, showing that the rate and degree of serum folate depression was not merely the result of the folate-deficient diet.

Subsequently, the alcohol was restarted and maintained for $4-4 \frac{1}{2}$ wk while repeated hematologic and ferrokinetic studies were performed. In the subject with the higher initial folate level, the serum folate level rapidly declined to $6 \mathrm{ng} / \mathrm{ml}$ and the serum iron level rose from 80 to above $200 \mu \mathrm{g} / 100 \mathrm{ml}$. The serum iron level remained elevated throughout the second period on alcohol without any change in plasma iron turnover or in utilization of radioiron in erythrocyte production, and without the development of megaloblastic erythropoiesis.

In contrast, the subject with the lower initial folate level had a rapid fall in serum folate level to below 2 $\mathrm{ng} / \mathrm{ml}$ and showed signs of megaloblastic erythropoiesis within 10 days of restarting the alcohol. By the 20th day, marrow morphology was classically megaloblastic. At this time, the plasma iron turnover had risen to 1.5-1.8 $\mathrm{mg} / 100 \mathrm{ml}$ packed cells per day (basal levels $0.6-0.8$ $\mathrm{mg} / 100 \mathrm{ml}$ per day). Ineffective erythropoiesis was documented by demonstrating a subnormal radioiron utilization, a reduced reticulocyte count $(<1.0 \%)$, and a gradually declining hematocrit. These abnormalities all reverted promptly to normal when alcohol was stopped and a normal diet was resumed.

\section{DISCUSSION}

The classical study of Sullivan and Herbert suggested that alcohol interferes directly with folate and iron metabolism by the marrow (9). A toxic effect of alcohol on the marrow at a cellular level is also suggested by the vacuolization of erythrocyte precursors (21), the depressed radioiron utilization (22), and the ring sideroblasts $(6,7)$ reported in some alcoholic patients. The present study implicates a possible interference by alcohol with the supply of folate to the marrow.

It has been suggested that alcohol, by mechanisms yet unknown, can accelerate by several weeks the appearance of megaloblastic anemia in subjects on a low folate diet $(1,8)$. In the subjects of this study, the mean fall in serum folate level during the first few days of a low folate diet plus alcohol was significantly greater than that observed on a low folate diet alone (Table I). This dif-

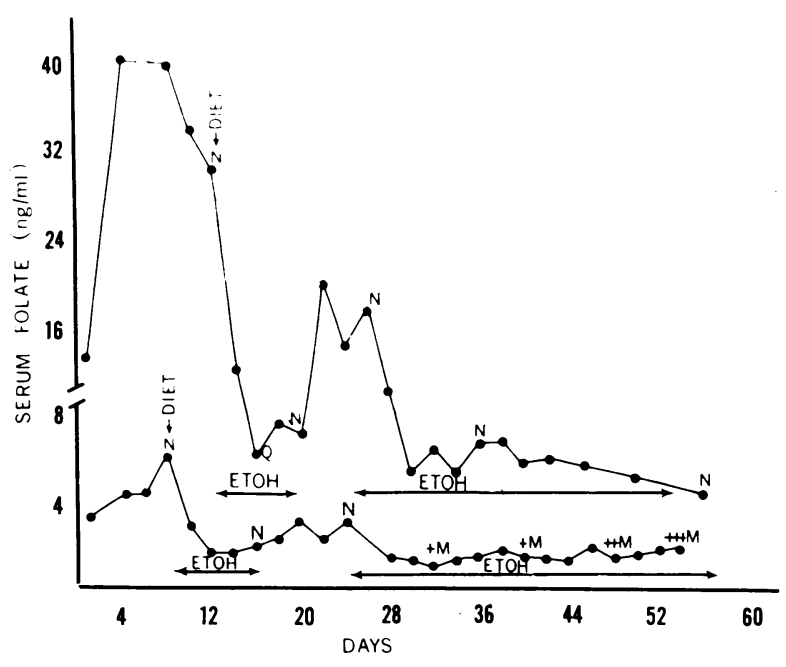

FIGURE 3 Serial serum folate levels in two subjects who received the low folate diet and ethanol for several weeks. Times of alcohol intake are shown (ETOH arrows). Normal marrow is denoted by $N$ and megaloblastic marrow by $M$. In both subjects the serum folate level fell on alcohol, rose when alcohol was temporarily stopped, and fell when alcohol was resumed. Only the subject with an initially marginal serum folate level developed a subnormal serum folate level and megaloblastic anemia.

ference was felt not to be attributable to differences in caloric content of the regimens because a form of caloric substitution was attempted for subjects not receiving alcohol, and the changes in body weight were comparable in the two groups. Thus, alcohol, per se, seems not only to accelerate the appearance of megaloblastic anemia, but also to accelerate the fall in serum folate level as measured by the $L$. casei assay.

To focus further on these alcohol-induced changes in folate metabolism, volunteers were given alcohol under different protocols. Subjects who drank 1 ounce of alcohol every $2 \mathrm{~h}$ had a greater than $50 \%$ fall in serum folate level within the first 16-20 h (Fig. 1). Though single short-term intravenous infusions of ethanol caused no decrease in serum folate level, a $13 \mathrm{~h}$ ethanol infusion caused a rapid fall in serum folate level between the 8 th and 10 th $\mathrm{h}$. Since this subject fasted throughout the study, the abrupt fall in serum folate level could not have been caused by reduced absorption of dietary folate. This fall was not accompanied by increased urinary loss of folate and was rapidly reversed when ethanol was stopped (Fig. 2).

These dramatic changes in serum $L$. casei folate level in subjects receiving alcohol initially suggested that alcohol and/or its metabolites interfered with the $L$. case $i$ assay. Yet the experiments described in this study militate against a simple assay artifact. The in vitro experiments rule out the possibility that physiologic levels of alcohol and its metabolites inhibit the growth of $L$. case $i$

Effect of Alcohol on Serum Folate Level 589 
or interfere with the growth-promoting effect of added folic acid or $n$-5-methyltetrahydrofolic acid. These experiments also disprove the hypothesis that alcohol interferes with possible nonfolate $L$. casei growth factors.

The osmotic effect of alcohol was shown not to influence the $L$. case $i$ assay by in vitro experiments and by the lack of fall in serum folate level during the shortterm intravenous ethanol infusions. Since alcohol distributes throughout total body water (20), it would not be expected to cause marked fluid shifts that might dilute plasma folate. Likewise, the fluid shifts after decreased secretion of antidiuretic hormone mediated by rising blood alcohol levels would not be expected to dilute plasma folate. Finally, the early fall in serum folate level induced by alcohol cannot be attributed to the recently described ethanol-induced increase in blood and urinary ketone levels, because significant accumulation of these metabolites is not seen until the subject has been on alcohol for several days (23).

To test the significance of the alcohol-induced fall in serum folate level, two volunteers were given alcohol and a low folate diet for several weeks. One subject was chosen because of normal folate stores (which were further supplemented with folic acid) and the other subject was chosen because of marginal folate stores. The ingestion of alcohol caused a fall in serum folate level in both subjects. However, while the subject with initially marginal folate stores developed megaloblastic anemia in little more than $3 \mathrm{wk}$, the subject with initially normal folate stores failed to develop subnormal serum folate levels or megaloblastic erythropoiesis during almost 7 wk of a similar regimen (Fig. 3 ). This study thus defines a limit on the in vivo effects of alcohol and directs attention to the relationship between the level of folate stores and the effects of alcohol.

Folate metabolism in man may be divided into the variables of absorption, conversion, storage, tissue utilization, and excretion. It seems unlikely that the two subjects above had significantly different levels of tissue utilization. While there may be individual differences in absorption of dietary folate, it is unlikely that such differences were great enough to account for the different courses observed here, particularly since both subjects were on a diet very low in folate. Data are presented which show that urinary excretion of folate was not significantly enhanced by alcohol. Although biliary and fecal excretion of folate were not studied, it seems unlikely that there would be individual differences in these functions great enough to account for these different courses. It thus seems reasonable to assume that the significant differences between the two subjects above were the variables of folate stores and/or conversion of absorbed folic acid to $n$-5-methyltetrahydrofolic acid.
Direct evidence is not yet at hand to prove that alcohol impairs the handling of folate stores. A strong indicator of such an effect is the rapid rebound in serum folate level when alcohol is stopped. This rebound occurs despite continuation of the low folate diet. Furthermore, the magnitude of the rebound seems to reflect the size of folate stores. Alcohol thus appears to make normal folate stores unavailable for the support of normal levels of serum folate. This conclusion directs attention to the mechanisms of conversion of folic acid to $n-5$ methyltetrahydrofolic acid in the liver (and/or intestinal mucosa) and to the kinetics of delivery of stored $n-5$ methyltetrahydrofolic acid to the circulation. It seems likely that alcohol interferes with one or more of these mechanisms to cause a rapidly reversible inhibition of folate supply.

\section{ACKNOWLEDGMENTS}

We are indebted to Ms. Caryl Campbell and Ms. Val Dickson for expert technical assistance and to Dr. Jim Johnson and Mr. Henry George for the osmometry.

This work was supported in part by the American Heart Association Grant no. 67-680 and U. S. Public Health Service Grant AM-13732 and RR-133 from the General Clinical Research Centers Program of the Division of Research Resources, National Institutes of Health.

\section{REFERENCES}

1. Eichner, E. R., and R. S. Hillman. 1971. The evolution of anemia in alcoholic patients. Am. J. Med. 50: 218.

2. McFarland, W., and E. P. Libre. 1963. Abnormal leukocyte response in alcoholism. Ann. Intern. Med. 59: 865.

3. Cowan, D. H., and J. D. Hines. 1971. Thrombocytopenia of severe alcoholism. Ann. Intern. Med. 74: 37.

4. Lindenbaum, J., and C. S. Lieber. 1969. Hematologic effects of alcohol in man in the absence of nutritional deficiency. N. Engl. J. Med. 281: 333.

5. Eichner, E. R., B. Buchanan, J. W. Smith, and R. S. Hillman. 1972. Variations in the hematologic and medical status of alcoholics. Am. J. Med. Sci. 263: 35.

6. Hines, J. D. 1969. Reversible megaloblastic and sideroblastic marrow abnormalities in alcoholic patients. $\mathrm{Br}$. J. Haematol. $16: 87$.

7. Hines, J. D., and D. H. Cowan. 1970. Studies on the pathogenesis of alcohol-induced sideroblastic bone-marrow abnormalities. N. Engl. J. Med. 283: 441.

8. Eichner, E. R., H. I. Pierce, and R. S. Hillman. 1971. Folate balance in dietary-induced megaloblastic anemia. N. Engl. J. Med. 284 : 933.

9. Sullivan, L. W., and V. Herbert. 1964. Suppression of hematopoiesis by ethanol. J. Clin. Invest. 43: 2048.

10. Eichner, E. R., N. Buergel, and R. S. Hillman. 1971. Experience with an appetizing, high protein, low folate diet in man. Am. J. Clin. Nutr. 24: 1337.

11. Herbert, V. 1966. Aseptic addition method for Lactobacillus casei assay of folate activity in human serum. J. Clin. Pathol. (Lond.). 19: 12.

12. Bothwell, T. H., and C. A. Finch. 1962. Iron Metabolism. Little, Brown, and Company, Boston. 
13. Stiles, D., J. G. Batsakis, B. Kremers, and R. O. Briere. 1966. The evaluation of ethanol measurements with alcohol dehydrogenase. Am. J. Clin. Pathol. 46: 608.

14. Chanarin, I., D. L. Mollin, and B. B. Anderson. 1958. The clearance from the plasma of folic acid injected intravenously in normal subjects and patients with megaloblastic anaemia. Br. J. Hacmatol. 4: 435.

15. Metz, J., K. Stevens, S. Krawitz, and V. Brandt. 1961. The plasma clearance of injected doses of folic acid as an index of folic acid deficiency. J. Clin. Pathol. (Lond.). 14: 622.

16. Mendelson, J. H. 1970. Biologic concomitants of alcoholism. N. Engl. J. Med. 283: 24.

17. Crouse, J. R., C. D. Gerson, L. M. DeCarli, and C. S. Lieber. 1968. Role of acetate in the reduction of plasma free fatty acids produced by ethanol in man. J. Lipid Res. 9: 509.
18. Lieber, C. S. 1967. Metabolic derangement induced by alcohol. Annu. Rev. Med. 18: 35.

19. Lieber, C. S., C. M. Leevy, S. W. Stein, W. S. George, G. R. Cherrick, W. H. Abelmann, and C. S. Davidson. 1962. Effect of ethanol on plasma free fatty acids in man. J. Lab. Clin. Med. 59: 826.

20. Robinson, A. G., and J. N. Loeb. 1971. Ethanol ingestion-commonest cause of elevated plasma osmolality? N. Engl. J. Med. $284: 1253$.

21. McCurdy, P. R., L. E. Pierce, and C. E. Rath. 1962. Abnormal bone-marrow morphology in acute alcoholism. N. Engl.J. Med. 266: 505.

22. Waters, A. H., A. A. Morley, and J. G. Rankin. 1966. Effect of alcohol on haemopoiesis. Br. Med. J. 2: 1565.

23. Lefèvre, A., H. Adler, and C. S. Lieber. 1970. Effect of ethanol on ketone metabolism. J. Clin. Invest. 49: 1775 . 